de servir al curioso para seguir por su cuenta el estudio del misterioso autor de Granada la bella.-R. Silva Castro.

\section{LA VIE dE BAKOUNINE, por Hélène Iswolsky.}

El primero de Julio de 1876 murió en Berna Miguel Bakunin, uno de los directores de la Primera Internacional, adversario de Carlos Marx. Revolucionario, escritor, apóstol de la destrucción, como se le llamó muchas veces, Bakunin fué un hombre de vida admirable, novelesca, agitada, ardiente. Fué amigo de Ricardo Wagner, de Herzen y de muchos artistas y pensadores europeos.

En 1849, a raíz de una revuelta sucedida en Dresden, revuelta donde Wagner también tomó parte, Bakunin fué detenido, y de presidio en presidio llegó hasta San Petersburgo, donde fué encerrado en la fortaleza de San Pedro y San Pablo. Como habia sido acusado de tomar parte en un complot polaco, el Zar lo había reclamado. Una vez en poder de las autoridades rusas, de quienes era muy conocida la actuación revolucionaria de Bakunin, Nicolás I sabiendo que el revolucionario había dado ya pruebas de indomable coraje, despreciando varias veces la pena de muerte con que se le había amenazado, renunció a la instrucción e interrogación de los jueces, confiando a su habilidad la tarea de sacar al autor de El individuo y el Estado la verdad que necesitaba. Envió al conde Orlof con un mensaje que decía:

El Emperador desea que le escribáis como un hijo escribiría a su padre espiritual.

$\mathrm{Y}$ atendiendo este llamado, que él creyó de buena fe y que en parte lo era, Bakunin escribió sus Confesiones, especie de historia de su vida, que empezaba en su infancia y terminaba en el momento de su encarcelamiento. Durante mucho tiempo este documento permaneció guardado en los archivos del Imperio, pero cuando los bolcheviques asumieron el poder, las Confesiones de Bakunin vieron ia luz pública. Este documento extraordinario, aunque no abarca sino los treinta primeros años de su vida, sirve para explicar toda la carrera y la vida de Bakunin. Está prolijamente anotado por el Zar Nicolás I.

En él se muestra Bakunin como un hombre arrepentido de sus pecados, y así lo proclama. Pero este arrepentimiento era sólo superficial. Permaneció durante ocho años en la fortaleza de San Pedro y San Pablo y en 1857 , atendiendo las repetidas súplicas del prisionero, Alejandro II lo deportó a Siberia. De allí escapó y después de un viaje que duró cinco meses, viaje el más largo que haya podido realizar un evadido, arribó a San Francisco (Estados Unidos), de donde se dirigió a Europa en demanda de sus compañeros, con los cuales reanudó su antigua vida de agitación obrera. Después de una serie de aventuras, fué a morir en Berna.

Al día siguiente de su muerte, un policía fué a interı ogat al camarada 
Vogt, en brazos del cual había fallecido Bakunin, sobre la identidad del difunto. Vogt no sabía qué decir. Por fin, intentó explicar al guardia que Bakunin había sido un revolucionario, un anarquista. Pero el guardia se alzó de hombros:

-Eso de revolucionario no quiere decir nada. ¿Tenía algún oficio? ¿Era rentista?

Vogt se acordó de que los admiradores de Bakunin le habían regaladoo intentado regalar-una villa y se lo dijo al guardia, quien apuntó en su carnet:

-Miguel Bakunin, rentista.

Así desapareció el apóstol de la destrucción universal, de quien Hélène Iswolsky ha escrito una biografía minuciosa y exacta.-Manuel Rojas.

\section{POESIA}

Poetisas de América. La poesía FEMENINA EN AMÉRICA, pOr María Monvel.

He aquí un libro (1) que puede sugerir innumerables reflexiones y que levanta preguntas de mucho peso. La propia recolectora de la antología, poetisa distinguida, se interroga:

¿Por qué hay en América tantas poetisas?Sería interesante que alguien quisiera puntualizar algunas observaciones sobre la cuestión.

(1) Editorial Nascimento. Santiago, 1930.
Desde luego, ella renuncia a responderse, y en el brevísimo espacio de su estudio preliminar (abarca solo cuatro páginas) no es posible agotar una cuestión $\tan$ considerable. Sin embargo, insinúa una idea que debe servir para llevarnos más adentro en el problema. En efecto, dice que Delmira Agustini y la Condesa de Noailles shan sido, sin duda, ios dos grandes modelos * de la poesía de las mujeres americanas. Los caracteres distintivos de estos dos influjos se definen asi:

Sensualidad de todos los sentidos, correspondiente a madame de Noailles, y sensualidad exclusivamente erótica correspondiente a la Agustini.

Ya tenemos, pues, un rasgo común: las mujrees americanas cantan sensaciones, y dentro de ellas prefieren las amorosas. Lo piueba, para todo el que no conozca de antemano la poesía femenina de América, esta antología, que es un muestrario de dieciocho de las principales poetisas americanas. Si los términos no corrieran el riesgo de ser interpretados equivocadamente, yo diría que es esta la primera antología de la indecencia que se hace en tierras de América. Es curioso, todas o casi todas las señoras y señoritas que se han dedicado a la poesía en este continente son mujeres muy de su hogar. que generalmente han constituido una familia y desenvuelven una vida discreta junto a su marido y a sus hijos, las que los tienen, y junto a su madre y demás familiares, las solteras. Sin embargo, en sus versos parecen bacantes ebrias, que no hubiesen tenido otra preocupación que 